\title{
KOMUNIKACJA PRZEZ RUCH - RUCH ROZWIJAJĄCY WERONIKI SHERBORNE JAKO METODA PRACY DLA OSÓB Z TRUDNOŚCIAMI ZE SPEKTRUM AUTYZMU
}

\section{COMMUNICATION THROUGH MOVEMENT - SHERBORNE DEVELOPMENTAL MOVEMENT METHOD OF WORKING WITH PEOPLE WITH AUTISM SPECTRUM DISABILITIES}

\author{
Iwona Strzałkowska-Nowak ${ }^{1(\mathrm{~A}, \mathrm{~B}, \mathrm{C}, \mathrm{D}, \mathrm{E}, \mathrm{F}, \mathrm{G})}$ \\ ${ }^{1}$ Uniwersytet Jana Kochanowskiego w Kielcach
}

Strzałkowska-Nowak, I. (2018). Komunikacja przez ruch - Ruch Rozwijający Weroniki Sherborne jako metoda pracy dla osób z trudnościami ze spektrum autyzmu. Rozprawy Społeczne, 12(4), 65-74. https://doi.org/10.29316/rs.2018.38

\author{
Wkład autorów: \\ A. Zaplanowanie badań \\ B. Zebranie danych \\ C. Dane - analiza i statystyki \\ D. Interpretacja danych \\ E. Przygotowanie artykułu \\ F. Wyszukiwanie i analiza \\ literatury \\ G. Zebranie funduszy
}

Tabele: 1

Ryciny: 3

Literatura: 20

Otrzymano: grudzień 2017

Zaakceptowano: lipiec 2018

\section{Wprowadzenie}

Ruch towarzyszy człowiekowi już od momentu poczęcia. Dziecko poruszające się w łonie matki dostarcza jej mnóstwo emocjonalnych wrażeń, głównie pozytywnych. Już wtedy można zaobserwować jak istotna i przyjemna może być komunikacja niewerbalna. Moment przyjścia na świat jest równie mocno powiązany z komunikacją pozasłowną - poprzez ruchy całego ciała i płacz, dziecko komunikuje wszystkim, że nowe środowisko nie jest of a close contact.

\begin{abstract}
Streszczenie
Zarówno ruch, jak i komunikację możemy zaliczyć do grupy podstawowych potrzeb każdego człowieka. Artykuł podejmuje tematykę komunikacji poprzez ruch, wykorzystywanej w pracy za pomocą Metody Ruchu Rozwijającego Weroniki Sherborne. Treść odnosi się do pracy z uszczegółowioną grupą odbiorców-osoby ze spektrum autyzmu. W pracy przedstawiono teoretyczne ujęgenezę Metody Ruchu Rozwijającego Weroniki Sherborne jak również praktyczne jej zastosowanie w pracy z osobami ze spektrum autyzmu w celu komunikacji z otoczeniem za pomocą ruchu własnego ciała jak i obserwacji ruchu ciała innych osób. Metoda Ruchu Rozwijającego zakłada posługiwanie się ruchem jako narzędziem wspomagania rozwoju psychoruchowego. Jest to efektem rozwijania poprzez ruch świadomości własnego ciała, przestrzeni, usprawnienia ruchowego oraz dzielenia przestrzeni z innymi osobami i nawiązywania z nimi bliskiego kontaktu za pomocą ruchu.
\end{abstract}

Słowa kluczowe: komunikacja, ruch rozwijający, Metoda Ruchu Rozwijającego Weroniki Sherborne, spektrum autyzmu, osoby z ASD

\section{Summary}

Movement and communication can be classified as a group of basic needs of each person. The article deals with the subject of communication through movement, used in the developing Sherborne Developmental Movement Method. The content refers to the work conducted with a specific group of learners with the autism spectrum. Theoretical approaches to communication as well as ways of communicating with ASD are presented. In addition, the genesis of the Veronica Sherborne Developmental Movement Method is also shown, as well as its practical use in the work with people with Autism Spectrum to communicate with the environment through the movement of one's own body and the observation of other people's body movements. The Developmental Movement Method considers the use of motion to be a significant tool to support psychomotor development. It results from the development of consciousness of one's body, of space, of movement, of space and of other persons, and of communication with others by means

Keywords: communication, developmental movement, Veronica Sherborne Developmental Movement Method, Autism Spectrum, ASD persons

dla niego tak przyjazne jak łono matki. Z biegiem czasu jednak dziecko stopniowo poznaje otoczenie i przekonuje się, że nowa rzeczywistość potrafi być równie sprzyjająca i bezpieczna. Nieodzownym elementem budowania takiego przekonania jest szeroko pojęta komunikacja. Dziecko odbiera świat dzięki napływającym bodźcom, informacjom i obserwacji rzeczywistości. W procesie socjalizacji nabywa zdolności funkcjonowania społecznego, poruszania się w świecie wedle obowiązujących norm, wartości i wzorców. Wszystkie te informacje

Adres korespondencyjny: Iwona Strzałkowska-Nowak, Uniwersytet Jana Kochanowskiego w Kielcach, Wydział Pedagogiczny i Artystyczny, Instytut Pedagogiki i Psychologii, ul. Krakowska 11, 25-029 Kielce, e-mail: iwona1992strzalkowska@gmail.com, tel.: 41 349 67 25/80, ORCID: https://orcid.org/0000-0002-0579-6381

Copyright by: Państwowa Szkoła Wyższa im. Papieża Jana Pawła II w Białej Podlaskiej, Iwona Strzałkowska-Nowak 
docierają do niego określonym kanałem za pośrednictwem różnego rodzaju kodów.

Problem pojawia się wówczas, gdy kanał komunikacyjny napotyka na zakłócenia. Proces komunikacji staje się wtedy dysfunkcyjny, co niesie ze sobą szereg konsekwencji. Takie zjawisko można zaobserwować wśród osób z całościowymi zaburzeniami ze spektrum autyzmu. Należy zatem szukać takich form komunikacji, które będą optymalne, zarówno dla osób z ASD (z ang. Autism Spectrum Disorder - zaburzenia ze spektrum autyzmu) jak i środowiska, w którym funkcjonują. Wykorzystując w odpowiedni sposób ruch można temu podołać. Zanim jednak powyższe stwierdzenie zostanie rozwinięte, dla szerszego zrozumienia podejmowanej tematyki należy przybliżyć kwestie teoretyczne dotyczące samego procesu komunikacji.

\section{Komunikacja - ujęcie teoretyczne}

Komunikacja (łac. communicatio - współudział, rozmowa) to w szerokim znaczeniu proces wymiany, interakcji. Swoje zastosowanie znajduje między innymi w cybernetyce, lingwistyce czy pedagogice. Podstawowy model komunikacji to dwaj partnerzy, z których jeden nadaje informację (zjawisko to nazywamy kodowaniem i emisją), a drugi odbiera (recepcja) i odczytuje tę wiadomość w procesie dekodowania. Jak podaje Nowy Słownik Pedagogiczny informacje mogą być przekazywane za pomocą trzech kanałów: optycznego, akustycznego i wizualnego (Okoń, 2004). Ruch wpisuje się w ten ostatni. Autor artykułu za zasadne uznaje dodanie czwartego kanału - sensorycznego/dotykowego, w którym to komunikat nadawany i odbierany byłby za pośrednictwem dotyku (ruchu, nacisku, siły, intencji i interpretacji). Nadawca jak i odbiorca muszą dobrze opanować posługiwanie się danym kodem i znać zasady ich łączenia. Bez tego nie można mówić o komunikacji.

Komunikacja interpersonalna wiąże się z wymianą informacji pomiędzy nadawcą i odbiorcą. Treści przekazywane są za pośrednictwem określonego kanału. Zakłada się, że przekazana informacja-komunikat, rozumiany jako wszelki skończony zbiór znaków, będący porcją informacji, ma wpłynąć na zachowanie odbiorcy (Okoń, 2004).

Komunikacja językowa to wymiana informacji pomiędzy nadawcą a odbiorcą za pomocą środków językowych. Aby zaistniała muszą wystąpić następujące elementy:

1. Nadawca komunikatu

\section{Odbiorca komunikatu}

3. Komunikat

4. Kontekst

5. Kontakt

6. Kod (Krawczyk i in., 2007)

Komunikacja niewerbalna to wymiana informacji pomiędzy nadawcą a odbiorcą środkami niejęzykowymi, np. poprzez gest, strój, mimikę czy właśnie ruch. (Tomczyk, Zarych, 2007)

Komunikując się z drugą osobą, niezależnie od wyboru kanału informacji, zawsze jakaś część komunikatu przekazywana jest poza świadomością nadawcy.

Do sygnałów, które nadawane są w sposób świadomy zalicza się gesty zastępujące słowa. Wśród nich wyróżnić można m.in. machanie na pożegnanie lub w celu zwrócenia uwagi, podniesienie ręki jako znak chęci zabrania głosu, jak również język migowy. Świadomie stosowane są również gesty, które mają na celu wzmocnienie wypowiadanego komunikatu, tj. ruch głową w górę i w dół jako potwierdzenie, czy w prawo i w lewo jako zaprzeczenie. Ponadto zamierzone i planowane są sygnały dające ogólną informację o nadawcy. Przykładem będzie tu m.in. obrączka na palcu czy strój np.: mundur, habit, garnitur (Tomczyk, Zarych, 2007).

Do sygnałów nadawanych bez udziału woli zaliczane są takie komponenty jak wiek, płeć, temperament, jak również te przedstawiające rozmówcę: czerwienienie się, zmiana barwy głosu, drżenie rąk/głosu. Nieświadomie podawane są też informuje o emocjach nadawcy poprzez gesty, tj. nerwowe zaciskanie dłoni czy drapanie się po czole oraz mimowolną mimikę. Bez udziału woli jawi się również stan zdrowia (Tomczyk, Zarych, 2007).

Jak już wspomniano ruch wpisuje się w ramy komunikacji niewerbalnej. Psychologia komunikacji podaje, iż proces wymiany informacji bez użycia języka odbywa się po części nieświadomie i zachodzi tylko wtedy, gdy uznamy wypowiedź za zbyteczną, poważną lub po prostu nudną. Wspomaga ją system sygnałów, który może zastępować mowę, towarzyszyć wypowiedzi. Dodatkowo może stanowić jakąś odrębną formę wypowiedzi popartą odpowiednim kontekstem lub być standaryzowanym sygnałem (Benesch, 2002).

Ujmując ruch $w$ kategoriach formy przekazu niewerbalnego należy postrzegać ten proces jako bardziej świadomy (podobnie jak gesty czy ekspresja mimiki twarzy). Kontakt cielesny, będący wynikiem określonego (zamierzonego lub nie) ruchu, jest przykładem komunikacji przez ruch.

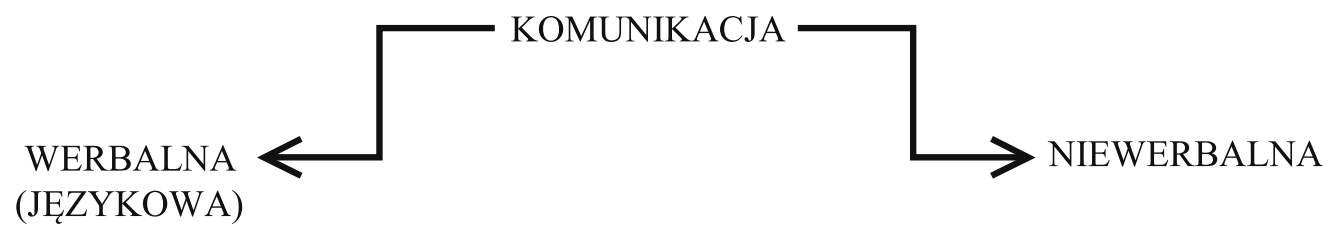

Rycina 1. Podstawowy podział komunikacji

Źródło: opracowanie własne. 
Pocałunek to czysta forma przekazania uczucia i akceptacji wobec drugiej osoby. Odepchnięcie czy uderzenie kogoś to również jasny komunikat postawy i intencji wobec odbiorcy. Taki sposób komunikacji często staje się jedynym dla osób ze spektrum autyzmu. Dlatego tak bardzo istotna jest obserwacja i praca ruchem w celu poprawy jakości komunikacji.

\section{Ruch Rozwijający Weroniki Sherborne - geneza metody}

Ruch jest bardzo ważnym elementem na każdym etapie rozwoju człowieka. Umożliwia bowiem działanie, aktywność, a także zaspokajanie podstawowych potrzeb człowieka. Umiejętność poruszania się daje dziecku możliwość eksploracji otoczenia, poznawania i uczenia się. Dzięki ruchom ciała można także wyrażać uczucia i komunikować się z innymi. Na te i inne wartości ruchu zwróciło uwagę wielu pedagogów XIX i XX wieku, m.in. Rudolf Steiner, Emil Jacąues-Dalcroze i Rudolf von Laban. Z czasem na znaczenie ruchu w rozwoju dziecka zwrócili również uwagę terapeuci, m.in. Karol Orff, TheaBu- gnet oraz Weronika Sherborne - uczennica Labana (Bogdanowicz i in., 1997).

Wagę ruchu dla rozwoju i komunikacji doceniono również w Polsce. Zwróciło na niego uwagę wiele wybitnych osób, takich jak Marta Bogdanowicz, Ewa Czarnecka, Alicja Kasica czy Maria Przasnyska, o czym świadczyć mogą liczne publikacje, podejmujące tematykę ruchu rozwijającego stosowanego $\mathrm{z}$ powodzeniem $\mathrm{w}$ terapii i edukacji. Ruch stwarza bowiem doskonałe możliwości wykorzystania komunikatu na wszystkich poziomach. Osoby, które mają trudności z komunikacją werbalną, podczas realizacji zadań wyrażają swoje uczucia w sposób nieumyślny. Jest to szczególnie widoczne podczas sesji ruchowych, w których aktywności mają charakter przelotny, a próba komunikacji może zostać niezauważona. Dlatego tak istotnym jest zgłębianie, analizowanie i świadomość ruchu w takiej wersji, jaką w danym momencie podaje nam osoba, a potem praktykowanie odpowiedniej higieny ruchu i nauka komunikowania się za jego pomocą (Sherborne, 2001). Weronika Sherborne uważa podobnie, o czym świadczyć mogą następujące słowa:(...) nauczyciele ruchu muszą być świadomi, które części cia-

Tabela 1. Analiza Ruchu

\begin{tabular}{|c|c|}
\hline $\begin{array}{c}\text { CIAŁO } \\
\text { Co się rusza/co robi }\end{array}$ & $\begin{array}{c}\text { PRZESTRZEŃ } \\
\text { Gdzie porusza się ciało }\end{array}$ \\
\hline CAŁE CIAŁO & POZIOMY \\
\hline $\begin{array}{l}\text { Tupanie, ślizganie, kręcenie, przeskakiwanie, turlanie, ska- } \\
\text { kanie, wskazywanie, wspinanie, czworakowanie, zastyga- } \\
\text { nie w bezruchu }\end{array}$ & Wysoko, nisko, średnio \\
\hline POSZCZEGÓLNE CZĘŚCI CIAŁA & KIERUNKI \\
\hline $\begin{array}{c}\text { Mogą: } \\
\text { prowadzić, wspierać, łączyć, poruszać się symetrycznie/ } \\
\text { asymetrycznie }\end{array}$ & $\begin{array}{c}\text { Do przodu/do tyłu } \\
\text { Po przekątnej/na boki } \\
\text { Do góry/na dół } \\
\text { Różne tory ruchu: zaokrąglony, prosty, zygzak }\end{array}$ \\
\hline $\begin{array}{l}\text { DYNAMIKA/ WYSIŁEK/ CECHY } \\
\text { Jak porusza się ciało }\end{array}$ & ZAKRESY \\
\hline CZAS & $\begin{array}{c}\text { Formy ciała: szeroki/wąski, zaokrąglony/prosty } \\
\text { Przestrzeń: osobista/ogólnodostępna } \\
\text { Zasięg ciała: blisko/daleko, duży/mały } \\
\end{array}$ \\
\hline Szybki, wygasający, wolny, nagły, średni & $\begin{array}{c}\text { RELACJE } \\
\text { Ruch z przedmiotami/ludźmi } \\
\end{array}$ \\
\hline SIŁA/ WAGA & PRZEDMIOTY \\
\hline $\begin{array}{c}\text { Silny/mocny } \\
\text { Lekki/ciężki } \\
\text { Odpowiedni/delikatny }\end{array}$ & $\begin{array}{c}\text { Nad/pod } \\
\text { w/na zewnątrz } \\
\text { pomiędzy dwoma/pomiędzy więcej niż dwoma } \\
\text { z przodu/z tylu } \\
\text { prowadzić/podążać za } \\
\text { powyżej/poniżej } \\
\text { przed/dookoła } \\
\end{array}$ \\
\hline PRZESTRZEŃ & LUDZIE \\
\hline $\begin{array}{c}\text { Bezpośrednia/prosto } \\
\text { Wielokierunkowa/okrężny }\end{array}$ & \multirow{3}{*}{$\begin{array}{l}\text { Odzwierciedlanie (lustro) } \\
\text { Naśladowanie (cień) } \\
\text { Jednocześnie } \\
\text { Razem/osobno } \\
\text { Zamiennie } \\
\text { Równocześnie } \\
\text { Partner/grupa } \\
\end{array}$} \\
\hline PRZEPŁYW & \\
\hline $\begin{array}{l}\text { Kontrolowany } \\
\text { Swobodny }\end{array}$ & \\
\hline
\end{tabular}

Źródło: Hill, 2013. 
ła się poruszaja, w jakim kierunku $w$ przestrzeni i co ważniejsze, jak porusza się ciało (Sherborne, 2001).

Weronika Sherborne z wykształcenia była nauczycielką wychowania fizycznego i fizjoterapeutką. Znajomość z Rudolfem Labanem, poznanie jego pracy i systemu nauczania wywarły decydujący wpływ na życie i twórczość Sherborne. W latach 60tych XX w. Sherborne wypracowała własny system ćwiczeń, który powstał na podstawie filozofii ruchu Labana. Autorka rozwinęła ją w kierunku humanistycznym, zwracając uwagę na potrzebę tworzenia i pielęgnowania bliskich związków między ludźmi, istotna dla rozwoju osobowości dziecka, niedocenianą i nierealizowaną w szkolnictwie. Idea wspomagania rozwoju dziecka przez nawiązanie więzi emocjonalnej z innymi ludźmi pogłębiła teorię Labana i stała się swoistą psychologią ruchu. Sherborne pojmowała ruch bardzo szeroko. Analizowała każdy, nawet najmniejszy jego przejaw. W oparciu o pracę Rudolfa Labana wyszczególniła pewne kategorie opisu ruchu, które ukazuje tabela1.

Metoda Ruchu rozwijającego (w skrócie MMR) jest stosowana we wspomaganiu prawidłowego rozwoju dzieci i korygowaniu jego zaburzeń. Istotą owej metody jest wykorzystanie ruchu (którego cechy wykazano w tabeli 1) jako narzędzia wspomagania rozwoju psychoruchowego dziecka oraz terapia zaburzeń rozwoju. Idea ćwiczeń Weroniki Sherborne ma swoje korzenie w zaspokajaniu naturalnych potrzeb dziecka w kontakcie z dorosłymi (por. z kategorią „relacje” w tabeli 1). Do podstawowych założeń metody zalicza się rozwijanie przez ruch świadomości własnego ciała i usprawniania ruchowego, świadomości przestrzeni i działania w niej, jak również dzielenia przestrzeni z innymi ludźmi i nawiązywania z nimi bliskiego kontaktu (Bogdanowicz i in., 1997).

Metoda Ruchu Rozwijającego, tak jak wcześniej wspomniano, opiera się na ruchu i relacji. Relacja jest tu rozumiana jako zabawa relacyjna, służąca do nawiązywania kontaktu z swoim partnerem. Do głównych celów zabawy relacyjnej należą: rozwijanie zaufania do samego siebie, świadomości własnego ciała, bezpieczeństwa emocjonalnego i fizycznego, a także rozwój komunikacji. Wyróżniamy trzy rodzaje zabawy relacyjnej: relacja opiekuńcza, czyli „z”; relacja „razem” i relacja „przeciwko” (Sherborne, 2002).

Pierwszy typ relacji, czyli relacja „z” buduje poczucie bezpieczeństwa, które otrzymywane jest od partnera. Ćwiczenia te można podzielić na: obejmowanie partnera, podtrzymywanie i podtrzymywanie zaawansowane. W tego typu ćwiczeniach jedno dziecko dowodzi - staje się opiekunem, dzięki czemu drugie może skupić się wyłącznie na doznaniach płynących z ćwiczenia. Należy pamiętać o tym, że przy wykonywaniu ćwiczeń tego typu należy na tyle, na ile to możliwe uwzględnić zamianę ról. Przykładem ćwiczeń w relacji „z” są : Kołyska, Turlanie, Ciągnięcie. Poniżej przedstawiono opis podanych ćwiczeń.
W Kołysce uczestnicy siedzą na podłodze. Młodszy partner znajduje się między nogami starszego. Starszy partner obejmuje młodszego ramionami, nogami i tułowiem. Delikatnie buja się $\mathrm{z}$ boku na bok, kołysząc go i podpierając kolanami, udami i ramionami. Ćwiczenie to pomaga zrelaksować się, odprężyć i wyciszyć. Efekt ten można zwiększyć poprzez ciche śpiewanie lub nucenie melodii w rytm kołysania. Turlanie - jak sama nazwa wskazuje, polega na obracaniu drugiej osoby wokół własnej osi po jakiejś powierzchni - materacu lub podłodze. Jest to przyjemny dla uczestnika sposób na uświadomienie mu faktu posiadania tułowia. W tym ćwiczeniu bowiem osoba czuje swój tułów w kontakcie z podłogą, materacem bądź innym podłożem. Odczuwa też swobodny przepływ ciężaru i ruch ciała jako całości, co wywołuje w nim uczucie harmonii. Należy zwrócić uwagę na to, by uczestnik turlał się w sposób jak najbardziej swobodny, nieskrępowany, a także ciągły. Można także spróbować wersji turlania się we dwoje. Należy jednak uważać, aby nie przygnieść swojego partnera w trakcie wykonywania ćwiczenia, szczególnie w relacji dorosły-dziecko. Mimo występowania częstych dysproporcji między partnerami, dzieci bardzo lubią podejmować wyzwanie zamiany ról i turlania osoby dorosłej lub starszej od siebie. Ciągnięcie polega na tym, że jeden z partnerów „ciągnie” drugiego po śliskiej podłodze, trzymając go za kostki u nóg. Sytuacja ta sprzyja często nawiązaniu kontaktu wzrokowego. Ciągnąc dziecko, starszy partner może wykonywać szerokie „poślizgi” na obie strony, powodując w ten sposób elastyczne wyginanie się ciała dziecka w talii. Nadaje to giętkości środkowej części ciała, zwiększa elastyczność ciała oraz powoduje jego rozluźnienie. Ćwiczenie to można także z powodzeniem wykonywać poprzez ciągnięcie drugiej osoby na kocu, co może ułatwić zadanie osobie ciągnącej (Sherborne, 2002).

Drugi typ relacji, czyli relacja „razem” polega na wykonywaniu ćwiczeń, w które są zaangażowani oboje partnerzy w jednym czasie. Do tego typu ćwiczeń możemy zaliczyć m.in. Wiosłowanie, Balansowanie z partnerem i Wahadło. Podczas wiosłowania obaj partnerzy siedzą na podłodze z wyciągniętymi na boki nogami zwróceni twarzami do siebie. Może się zdarzyć, że nogi jednego z partnerów będą musiały leżeć na nogach drugiego. Partnerzy chwytają się wzajemnie za nadgarstki, a bardzo małe dzieci starszy partner może trzymać za łokcie. Następnie każdy z partnerów przemiennie kładzie się do tyłu, potem znów siada i w końcu pochyla się do przodu, podczas gdy drugi kładzie się w tył na podłogę. W tym ćwiczeniu trzeba zwrócić uwagę na to, aby pomóc osobie pochylić się do tyłu, tak by oparła głowę całkowicie o podłogę (jest to charakterystyczna oznaka zaufania) oraz w sytuacji, gdy partnerami w ćwiczeniu są dziecko i osoba dorosła, która musi dyskretnie pomóc dziecku tak, by mogło ono także podnieść swojego partnera (nie należy jednak całkowicie wyręczać dziecka). Balansowanie z part- 
nerem to wspólne utrzymywanie równowagi. Partnerzy siadają na podłodze zwróceni twarzami do siebie z nogami zgiętymi w kolanach, mocno opartymi o podłoże i nieco rozstawionymi. Partnerzy chwytają się za przeguby rąk i mocno ciągnąc starają się razem podnieść do pozycji stojącej. Odległość między nimi powinna być dostosowana do długości ich ramion (które powinny być nieco ugięte). Następnie partnerzy mogą ponownie razem usiąść, nawzajem równoważąc swój ciężar ciała. Muszą utrzymać biodra dokładnie pod sobą, wystające do tyłu utrudniają utrzymywanie równowagi. Ćwiczenie to można zastosować także w wariancie na stojąco. Zadanie wymaga dużej koncentracji uwagi, panowania nad ruchem kontrolowanym oraz wzajemnego słuchania się partnerów. W wahadle jeden uczestnik podnosi się, gdy drugi opada. Mogą również siedzieć oparci o siebie plecami ze zgiętymi kolanami i stabilną podstawą. Tak mocno napierają na siebie plecami, że udaje im się wstać razem. Utrzymują równowagę dotykając się plecami wzdłuż całej długości kręgosłupa, a następnie razem siadają. Ćwiczenie to wymaga dobrej współpracy między partnerami w zakresie skoordynowania ruchu oraz silnych mięśni ud (Sherborne, 2002).

Ostatni typ relacji - relacja „przeciwko” składa się z takich ćwiczeń jak: Skała - partner pomaga mocno i pewnie usiąść na podłodze drugiemu, nogi zgięte w kolanach, stopy osobno, ręce mocno oparte $\mathrm{z}$ palcami rozłożonymi na podłodze. Jedna osoba jest „skałą”. Druga wypróbowuje „skałę” delikatnie napierając na kolana. Jeżeli ciało pierwszej opiera się naciskowi, druga może popchnąć trochę mocniej, ale nie wolno jej wypchnąć partnega z jego pozycji. Następnie osoba próbuje napierać z tyłu na bark uczestnika. Należy pamiętać o zamianie ról w tym ćwiczeniu, aby partnerzy mogli doświadczyć także oporu. Plecy-w-plecy to kolejny przykład ćwiczeń w relacji „przeciwko”, polegające na tym, że dwoje osób siada na podłodze, plecami do siebie. Ich nogi są zgięte w kolanach, stopy opierają się o podłogę, tworząc mocną i trwałą podporę z przo$\mathrm{du}$, a ręce podpierają tułów od tyłu. Teraz jeden z partnerów plecami pcha plecy drugiego, sprawdzając, jak silny daje opór, a w rezultacie dochodzi do pewnego rodzaju walki statycznej. Ćwiczenie to można ubarwić dzieciom poprzez wchodzenie w role np. samochodzików, motorków itd. Więzienie to ćwiczenie, w którym starszy partner buduje „domek - schowek”, siadając na podłodze z młodszym umieszczonym pomiędzy własnymi nogami. „Domek”, który z początku jest przyjaznym i wrażliwie reagującym pomieszczeniem - „kołyską”, obecnie staje się „więzieniem”, gdy ramiona i nogi starszego partnera chwytają młodszego i mocno się na nim zaciskają. Teraz zachęca się dziecko, aby wyślizgnęło się na zewnątrz przez „drzwi frontowe” (wyważając ramiona dorosłego), przez „boczne okna” lub w górę przez „komin”. Starszy partner pozwala dziecku uciec, wkładając w powstrzymywanie go dokładnie tyle siły, ile potrzeba, by musiało ono na- prawdę walczyć o wyswobodzenie się. W tego typu ćwiczeniach dziecko ma możliwość wypróbowania swoich sił przeciwko sile starszego partnera, dzięki czemu rozwija kontrolowaną siłę. Cwiczenia relacji „przeciwko” mają na celu ukierunkowanie i skanalizowanie energii uczestnika oraz rozwinięcie jego zdecydowania i determinacji. W relacji dziecka z starszym partnerem musi on pamiętać, aby zachęcać dziecko do wysiłku i włożenia wszystkich sił na jakie go stać, co nagradzamy pozwoleniem na wygraną dziecka. Ważne jest też, aby traktować relację „przeciwko” z humorem i przypominać, że jest to tylko forma zabawy. Pracując za pomocą Metody Ruchu Rozwijającego Weroniki Sherborne powinno się przeplatać powyższe formy zabawami relacyjnymi, aby dziecko miało możliwość rozwijania zaufania, współpracy, a także kontrolowania siły. W metodzie tej stosuje się także wiele różnorodnych ćwiczeń pozwalających na rozwijanie świadomości całego ciała, jak i jego części (Sherborne, 2002).

Metoda Ruchu Rozwijającego wykorzystuje język ciała, a więc ruch, który pozwala na porozumienie się pomimo różnicy języka mówionego, czy poziomu intelektualnego rozmówców. Główne założenia tej metody to rozwijanie świadomości własnego ciała i otoczenia, usprawnianie sfery motorycznej, dzielenie przestrzeni z innymi osobami oraz nawiązywanie bliskiego kontaktu za pomocą zarówno ruchu jak i dotyku. Ponadto zajęcia prowadzone tą metodą stymulują rozwój emocjonalny, społeczny i poznawczy dziecka. Weronika Sherborne ujmuje metodę w podejściu pedagogicznym, które ma na celu umożliwienie doświadczenia ruchu, kontaktu fizycznego, emocjonalnego oraz społecznego. Sam ruch natomiast pojmuje w kategoriach psychologiczno-filozoficznych, czyli znacznie szerzej niż tylko jako aktywność fizyczną (Dokowicz, 2015).

Podsumowując Metoda Ruchu Rozwijającego Weroniki Sherborne, bazując na bardzo prostych i klarownych ćwiczeniach ruchowych, wspomaga zarówno rozwój fizyczny jak i emocjonalny dziecka. Można wyróżnić wiele jej zalet. Przede wszystkim daje pozytywne odczucie w kontakcie $\mathrm{z}$ innym człowiekiem, wyzwala swobodę zachowań i naturalność, daje okazję do rozładowania energii. Ponadto jest próbą pokonania własnych zahamowań wynikających z uprzednich doświadczeń. Daje też radość, możliwość zaspokojenia własnych potrzeb, pewność siebie, możliwość znalezienia się w innej roli niż na co dzień, jak również wyzwala zaangażowanie i zbliża do siebie uczestników zajęć. Dzięki ćwiczeniom MRR uczestnicy odczuwają radość z działania w grupie, przyjemność wynikającą $\mathrm{z}$ dawania innym radości a także poczucie harmonii z innymi, partnerstwa. Możliwość odczuwania przyjemnych doznań płynących z własnego ciała to kolejna zaleta stosowania MMR. Poza tym, co należy bardzo mocno zaznaczyć, metodę tą można stosować wszechstronnie, zarówno w pracy z dziećmi 
w normie rozwojowej, jak również z dziećmi z zaburzeniami rozwoju, czy ze specjalnymi potrzebami edukacyjnymi (Bogdanowicz i in., 1997).

\section{Komunikacja poprzez ruch wśród osób z ASD za pomocą Metody Ruchu Rozwijającego Weroniki Sherborne}

Niejasności powstające wokół autyzmu znajdują swoje odbicie w liczbie terminów dotyczących tego zagadnienia. Mnogość objawów obserwowanych u osób autystycznych przemawia za tym, że prawdopodobnie nie mają one jednego wspólnego czynnika etiologicznego. Pod koniec lat siedemdziesiątych XX wieku LornaWing, brytyjska badaczka autyzmu, zauważyła, że nasilenie trudności specyficznych dla autyzmu nie jest jednakowe u wszystkich dotkniętych nim osób. Zaproponowała wówczas określenie „autystyczne kontinuum” (rycina 2) dla zilustrowania, że autystyczne zachowania oraz związane z nimi trudności można rozpatry wać jako pewien ciągły wymiar. całościowych zaburzeń rozwoju: autyzmu dziecięcego, Zespołu Aspergera oraz innych całościowych zaburzeń rozwoju. Przy aktualnym stanie wiedzy termin ten trudno uznać za precyzyjny. Warto jednak zwrócić uwagę na kilka zalet. Uwypukla on podobieństwo zachowania osób z kilkoma zaburzeniami klasyfikowanymi jako odrębne jednostki kliniczne. Poza tym pozwala uniknąć trudnego i obciążonego wieloma błędami różnicowania wewnątrz kategorii całościowych zaburzeń rozwoju.

Wiedza na temat autyzmu jest nieustannie poszerzana i weryfikowana. Ewolucyjne wersje klasyfikacji ICD-11 i DSM-V wprowadzają kolejne zmiany. W DSM-V nastąpiła likwidacja podziału jednostek chorobowych w obrębie całościowych zaburzeń rozwoju. Co za tym idzie, stworzona została ogólna grupa spektrum zaburzeń autystycznych, podzielona ze względu na natężenie symptomów. Obejmuje ona autyzm, zespół Aspergera, dziecięce zaburzenie dezintegracyjne i PDD-NOS (definiowane jako całościowe zaburzenie rozwoju nie zdiagnozowane inaczej). Z klasyfikacji usunięto Zespół Ret-

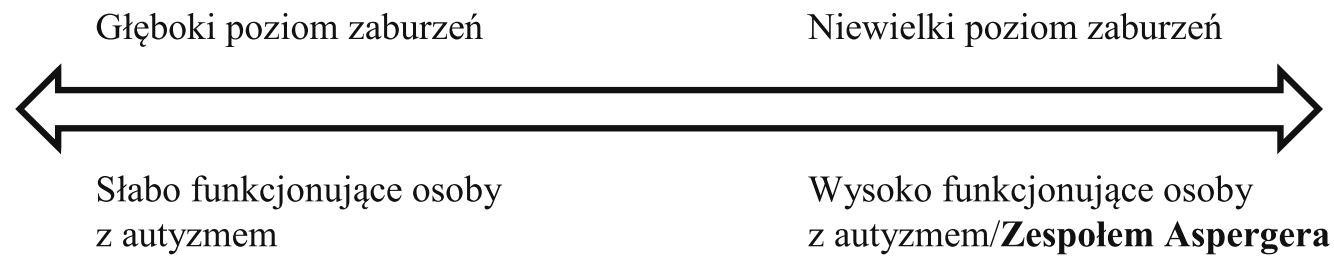

Rycina 2. Autystyczne kontinuum

Źródło: Opracowanie własne.

Lorna Wing podkreśliła, że w obrębie powyższego kontinuum znajdują się zarówno ciężkie formy zaburzenia z dużymi nieprawidłowościami, jak i znacznie lżejsze, które w mniejszym stopniu zakłócające rozwój człowieka. W efekcie spostrzeżeń poczynionych przez badaczkę rozszerzono koncepcję autyzmu o zaburzenia lżejsze i mniej typowe w stosunku do wyjściowego opisu. W 1988r. wprowadzono termin autystyczne spektrum zaburzeń (ASD - autistic spectrum disorders) (Pisula, 2010).

Autystyczne spektrum zaburzeń (według skali ICD-10) obejmuje osiem zaburzeń: autyzm dziecięcy, autyzm atypowy, Zespół Retta, inne dziecięce zaburzenia dezintegracyjne, zaburzenie hiperkinetyczne z towarzyszącym upośledzeniem umysłowym i ruchami stereotypowymi, Zespół Aspergera, inne całościowe zaburzenia rozwojowe a także jakościowe zaburzenia rozwojowe, nieokreślone (WHO, 1992).

Wszystkie te zaburzenia sa również określane mianem całościowych zaburzeń rozwoju. Termin ten wskazuje, że dotyczą wielu obszarów funkcjonowania człowieka i wpływają na jego rozwój jako całość (Kaczmarek, Wojciechowska, 2015). Określenia autystyczne spektrum używa się zazwyczaj w odniesieniu do trzech, najbardziej popularnych, ta. Zaproponowano zamienną nazwę dla zespołu Aspergera- autyzm subkliniczny/ autyzm lekkiego lub łagodnego stopnia z opisem występujących u dziecka cech, np. prawidłowo rozwinięta mowa, szeroka wiedza ogólna, specyficzne, wąskie zainteresowania. Nastąpiła również rewizja w obszarze kryteriów diagnostycznych. Zrezygnowano także z zapisu dotyczącego wieku („pierwsze symptomy pojawiają się przed ukończeniem 3 roku życia”) (American Psychiatric Association, 2013).

Obecnie DSM-V charakteryzuje zaburzenia ASD (Autism Spectrum Disorders) w zakresie dwóch obszarów. Jako pierwszy z nich wymienić należy deficyty w zakresie funkcjonowania społeczno-komunikacyjnego. Zaliczymy tu wszelkie dysfunkcje aparatu artykulacyjnego, jak również trudności z nawiązaniem i utrzymywaniem interakcji z drugim człowiekiem za pomocą komunikacji werbalnej i niewerbalnej. Trudności w tym zakresie to między innymi echolalia, pedantyczność mowy, fiksacje słowne i inne czynniki zakłócające poprawną komunikację. Do drugiego obszaru zaburzeń zaliczane są uporczywe zainteresowania i powtarzalne zachowania, tzn. stereotypie. Można do nich zaliczać zarówno fiksacje tematyczne, ruchowe, słowne jak i te skoncentrowane na konkretnych przedmiotach 
(np. nadmierne zainteresowanie chromowanymi częściami mebli lub zegarami). Międzynarodowa Klasyfikacja Chorób DSM-V podaje następujące kryteria diagnozy spektrum zaburzeń autystycznych:

A. Stałe deficyty w zakresie komunikacji społecznej i społecznej interakcji w różnych kontekstach, niewyjaśnione przez ogólne opóźnienia rozwojowe i manifestujące się przez wszystkie trzy rodzaje.

Pierwszy z nich to deficyty w zakresie społeczno - emocjonalnej wzajemności. Ich stopień może obejmować anormalne podejście społeczne i niepowodzenie w normalnej, dwustronnej konwersacji, przez zredukowanie dzielenia zainteresowań, emocji i afektu oraz reakcji, po całkowity brak inicjowania interakcji społecznej. Deficyty w zakresie zachowań o charakterze komunikacji niewerbalnej, używanych w celu interakcji społecznej to drugi rodzaj stałych deficytów w zakresie komunikacji społecznej. Począwszy od słabo zintegrowanej komunikacji werbalnej i niewerbalnej, przez anormalności kontaktu wzrokowego i języka ciała lub deficytów w zakresie rozumienia i stosowania komunikacji niewerbalnej, do całkowitego braku ekspresji twarzy lub gestów. Trzeci rodzaj to deficyty twarzy, dotyczące rozumienia i utrzymywania relacji, odpowiednio do poziomu rozwojowego (oprócz tych związanych $\mathrm{z}$ opiekunami). Ich stopień może być różny, począwszy od trudności w doborze zachowania do zastosowania w odpowiednich kontekstach społecznych, przez trudności w dzieleniu zabawy wyobrażeniowej i nawiązywaniu przyjaźni, po widoczny brak zainteresowania ludźmi.

B. Ograniczone, powtarzalne wzorce zachowania, zainteresowań lub aktywności(manifestujące się przynajmniej przez dwa spośród opisanych poniżej).

Wyróżniamy je spośród następujących trudności: stereotypowa lub powtarzalna mowa, ruchy lub posługiwanie się przedmiotami (jak proste stereotypie ruchowe, echolalia, powtarzalne używanie przedmiotów lub idiosynkratyczne frazy); nadmiernie wykorzystanie rutyny, zrytualizowanych wzorców zachowań werbalnych lub niewerbalnych lub nadmierny opór wobec zmiany (jak rytuały ruchowe, naciskanie na tą samą droge lub jedzenie, powtarzanie tego samego pytania lub skrajny stres w odpowiedzi na małe zmiany); wysoce ograniczone, uporczywe zainteresowania, anormalne pod względem intensywności lub przedmiotu uwagi (takie jak silne przywiązanie do lub zajmowanie się niezwykłymi obiektami, zainteresowania, które są nadmiernie zawężone lub powtarzające się), a także hiper lub hiporeaktywność na sensoryczny bodziec lub niezwykłe zainteresowanie sensorycznymi aspektami otoczenia (jak widoczna obojętność na ból, gorąco, zimno, negatywna reakcja na specyficzne dźwięki lub powierzchnie, intensywne wąchanie lub dotykanie przedmiotów, fascynowanie się błyskami światła lub wirującymi przedmiotami).
C. Symptomy muszą być obecne we wczesnym dzieciństwie (ale mogą się nie manifestować przed czasem, w którym społeczne wymagania ujawniają ograniczone możliwości).

D. Symptomy razem wzięte ograniczają i upośledzają codzienne funkcjonowanie.

Zaburzenie spektrum autyzmu jest zaburzeniem neurorozwojowym i musi być obecne od niemowlęctwa lub wczesnego dzieciństwa, ale może nie być rozpoznane $\mathrm{w}$ tym okresie, $\mathrm{z}$ powodu minimalnych wymagań społecznych i wsparcia ze strony rodziców oraz opiekunów dostarczanego we wczesnych latach życia dziecka (American Psychiatric Association, 2013).

Dzieci z autyzmem, mimo wielu cech wspólnych, wykazują duże, indywidualne różnice w zakresie samoobsługi, uspołecznienia, zachowania, jak i komunikacji i sprawności fizycznej. Ich rozwój ruchowy przebiega różnorodnie. U wielu dzieci początkowo brak jest odstępstw od normy, jednak pojawiają się opóźnienia w zakresie motoryki dużej. Często zauważyć można jednak dysharmonie ruchowe- dziecko wykazuje dużą sprawność w zakresie wykonywania czynności, które preferuje, zaś podczas pozostałych aktywności staje się motorycznie niezgrabne (Komender i in., 2012). W Wielkiej Brytanii przyjęło się określenie tego typu trudności mianem dyspraksji. Praksja to funkcja, która umożliwia planowanie ruchu. Dla pełniejszego zrozumienia podano przykład łapania piłki. Aby tego dokonać należy pierwotnie ocenić odległość oraz kierunek lotu piłki. Następnie analizie poddaje się trajektorię lotu i prędkość. W kolejnym kroku należy opracować metodę umożliwiającą znalezienie się $\mathrm{w}$ odpowiednim położeniu, przez które rozumiemy miejsce, w którym piłka spadnie na ziemię. Ostatnim zadaniem jest dotarcie w wyznaczone miejsce, wyciągnięcie rąk i zaciśnięcie ich dokładnie w chwili, gdy piłka znajdzie się miedzy nimi. Gdyby poproszono o to, by owe obliczenia przedstawić na papierze, zapewne niewielu potrafiłoby tego dokonać, ponieważ większość osób czyni tego typu obliczenia w głowie, niejako bezwiednie. Dyspraksja odzwierciedla przekonanie, że trudności osób z tym schorzeniem wynikają z nieumiejętności przeprowadzenia przytoczonego procesu (Platt, 2015).

Możliwości oddziaływania terapeutycznego celem usprawnienia osób z ASD jest wiele. Jedną $\mathrm{z}$ nich, wymienianą jako kategoria terapii wspomagającej jest Metoda Ruchu Rozwijającego Weroniki Sherborne. Jej skuteczność oceniana jest na podstawie efektów pracy z dzieckiem. Początkowo $\mathrm{w}$ terapii dzieci $\mathrm{z}$ autyzmem MRR traktowano jako eksperyment, mający na celu przede wszystkim przezwyciężanie ograniczeń społecznych. Skuteczność metody badano również w Polsce. Pierwsze próby analizy efektywności podjęto w Warszawie w latach 80. XXw. W 1994r Krajowe Towarzystwo Autyzmu (KTA) zaliczyło MRR do alternatywnych metod wspierania rozwoju dzieci (Bogdanowicz, Kasica, 2016). Efektywność oddziaływania terapeutycznego metody w pracy 
z dziećmi ze spektrum autyzmuoceniono wówczas bardzo wysoko. MMR umożliwiła bowiem oddziaływanie na najbardziej zaburzone sfery: emocjonalną, poznawczą i społeczną. Do dziś nie uległo to zmianie. Nadal bowiem możemy obserwować pozytywne oddziaływanie metody na rozwój powyższych sfer funkcjonowania osób z ASD. Dodatkowym atutem pracy Metodą Ruchu Rozwijającego jest możliwość udziału w sesjach opiekunów dzieci, jak również całej najbliższej rodziny. Umożliwia to kontynuację ćwiczeń w środowisku rodzinnym, a co za tym idzie, zacieśnianie wzajemnych relacji rodzinnych. Wspólne ćwiczenia członków rodziny pozwalają bowiem na wzajemne obniżanie poziomu lęku, związanego $\mathrm{z}$ potrzebą komunikacji potrzeb czy emocji, jak również funkcjonowania społecznego osoby z ASD. Potwierdzeniem tej tezy są liczne badania, m.in. Jacka Błeszczyńskiego (Komender i in., 2012).

Podczas udoskonalania sprawności motorycznych ważne jest, aby za punkt wyjścia do pracy obrać sobie zainteresowania i poziom rozwoju danego dziecka. Podczas zabawy czy ćwiczeń dorosły powinien poruszać się równolegle do dziecka i zajmować pozycję obok dziecka, a nie naprzeciw czy też na ukos od dziecka. Takie oddziaływanie na dziecko poprzez ruch równoległy to dla podopiecznego jasny komunikat: akceptuję Twoje trudności, rozumiem Twoje potrzeby, przy mnie możesz czuć się bezpieczny (Komender i in., 2012).

Metoda Ruchu Rozwijającego w pracy z osobami ze spektrum autyzmu wymaga przestrzegania tego, by nie forsować żadnego rodzaju aktywności ruchowych. Jako uzasadnienie podać należy fakt, że im większy będzie nacisk na wykonanie czegoś, z tym większym oporem się spotka, gdyż osoba będzie miała podwyższony poziom lęku i stresu (Hill 2013). Lepiej zmienić aktywność lub jej całkowicie zaprzestać na jakiś czas, dając tym jasny komunikat, że terapeuta rozumie i szanuje aktualny stan uczestnika osoby objętej terapią i traktuje je podmiotowo. Dodatkowo MRR w pracy z dziećmi $\mathrm{z}$ ASD kładzie nacisk na prace $\mathrm{w}$ relacjach $\mathrm{z}$ dorosłym głównie na poziomie podłogi. Oznacza to, że wszelkie sposoby aktywności proponowane przez trenera planowane są tak, by zarówno dziecko jak i opiekun mogli je wykonywać w jak najbliższym kontakcie z podłożem (w pozycji leżącej, pełzającej, czołgającej itp.). Jest to szczególnie istotne na początku pracy za pomocą MRR, ponieważ kontakt z podłogą daje znacznie większe poczucie bezpieczeństwa niż np. balans na jednaj nodze, przez co sprzyja efektywności w dalszej pracy. Organizacja sesji opiera się na poniższych zasadach:

1. Praca w małych grupach

2. Ustalona kolejność działań

3. Wprowadzanie nowych aktywności w sposób delikatny

4. Przygotowanie na realizację różnych aktywności w grupie w tym samym czasie (uwzględniając indywidualne potrzeby)
5. Czytelne sygnały na rozpoczęcie aktywności

6. Przygotowanie na konieczność używania pomocy dydaktycznych typu kolce, liny, obręcze itp., szczególnie w przypadku dzieci nadwrażliwych na dotyk (Hill 2013).

Weronika Sherborne powiedziała, że (...) wszystkie dzieci maja dwie podstawowe potrzeby: potrzebuja czuć się $w$ swoim własnym ciele jak $w$ domu oraz nawiqzzać relacje (Bogdanowicz, Kasica 2016). Podstawowym celem MRR jest zaspokajanie powyższych potrzeb, co w praktyce jest realizowane poprzez rozwijanie wśród uczestników dwóch aspektów świadomości. Jako pierwszą należy wymienić świadomość siebie- którą osiąga się poprzez doświadczenia ruchowe, pozwalające na skoncentrowaniu się na tym, co dzieje się z własnym ciałem. Wsłuchując się w nie odczuć można dotyk i bodźce płynące z jego wnętrza. To z kolei sprzyja podnoszeniu samoakceptacji i pozwala zyskać większą pewność siebie. Dzięki temu nie boimy się wchodzić w relacje z innymi, między innymi komunikując się za pomocą ruchu. Świadomość innych, pojmowana jako następny krok ku wchodzeniu w interakcje społeczne, bazuje na twierdzeniu, iż ruch pozwala na budowanie zaufania i pozytywnych relacji $z$ innymi. Udział w zajęciach grupowych metodą ruchu rozwijającego umożliwia uzyskanie odpowiedniego wsparcia i stanowi zachętę do odkrywania świata i innych ludzi, komunikując się z nimi za pomocą ruchu (Bogdanowicz, Kasica, 2016).

Temple Grandin - wysokofunkcjonująca, dorosła osoba $\mathrm{z}$ autyzmem, zaangażowana $\mathrm{w}$ popularyzację wiedzy o tym zaburzeniu, autorka wielu bestsellerów, w swoich wypowiedziach często podkreśla potrzebę kontaktu społecznego jako bardzo istotną dla samej osoby z ASD. Zwraca uwagę na fakt, iż osoby z całościowymi zaburzeniami ze spektrum autyzmu, pomimo powszechnie panującego przekonania o ich braku chęci lub umiejętności do wchodzenia $w$ interakcje społeczne, bardzo pragną komunikacji i kontaktu z drugim człowiekiem. Często jednak okazuje się, że problemem nie są dysfunkcję osób z ASD a brak zrozumienia lub wręcz niechęć do otwarcia się na relację ,które przejawiają osoby nieautystyczne (tzn. neurotypowe). Tu z pomocą przychodzi MRR. Bazując na ruchu pomaga w zbudowaniu relacji, nauce komunikacji i interpretacji ruchu jako jednego z kanałów komunikacji niewerbalnej.

Metoda Ruchu Rozwijajacego Weroniki Sherborne wykorzystuje dotyk, ruch oraz wzajemne relacje fizyczne, emocjonalne i społeczne do rozszerzania świadomości własnego ciała i usprawniania ruchowego, świadomości przestrzeni i działania w niej a także pogłębiania kontaktu z innymi ludźmi. Prezentuje to rycina 3. Dynamika relacji w grupie podczas zajęć prowadzonych Metodą Ruchu Rozwijającego Weroniki Sherborne. 


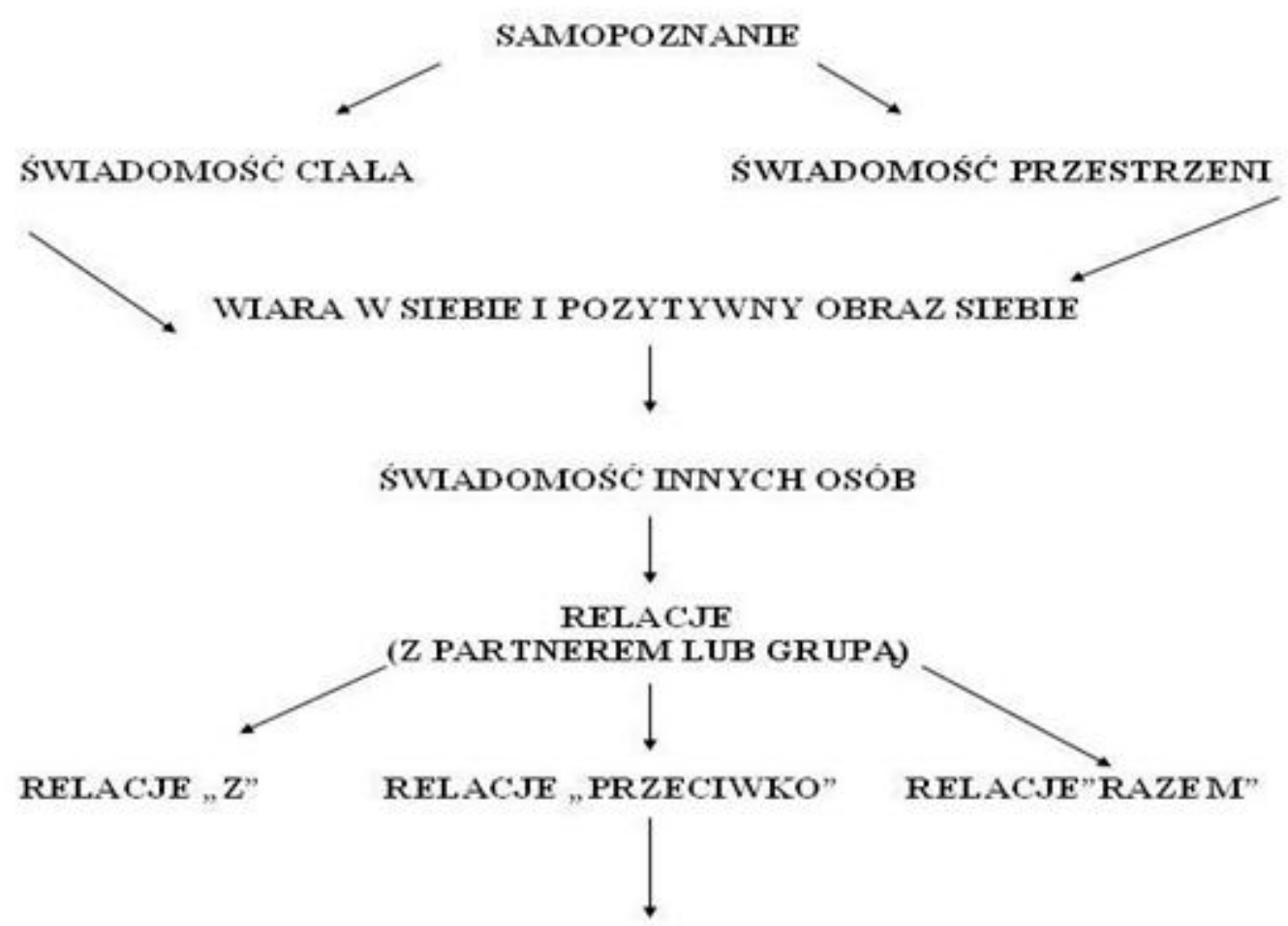

BEZPIECZENSTWO I WLARA W SIEBIE I INNYCH

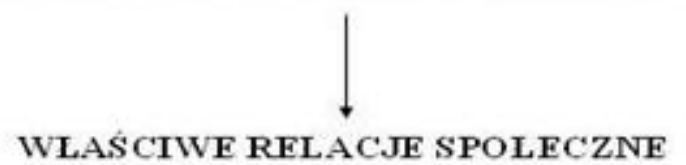

Rycina 3. Dynamika relacji w grupie podczas zajęć prowadzonych MRR

Źródło: Klinta, 1998.

\section{Podsumowanie}

Doświadczenie ruchu jest sprawa fundamentalnq dla rozwoju wszystkich dzieci, szczególnie istotne dla dzieci ze specjalnymi potrzebami edukacyjnymi, które często mają trudności zarówno w relacji ze swoim własnym ciałem, jak i z innymi osobami (Sherborne, 1990).

Zarówno ruch jak i komunikację możemy zaliczyć do grupy podstawowych potrzeb każdego człowieka. Metoda Ruchu Rozwijającego zakłada posługiwanie się ruchem jako narzędziem wspomagania rozwoju psychoruchowego (Bogdanowicz, Kasica, 2016). Aktywność ruchowa każdego człowieka jest zależna od jego rozwoju pod względem świadomości własnego ciała. Ważne jest, aby poznać swoje ciało, jego części oraz umieć wyodrębnić je z otoczenia, co rozwija się u dzieci do trzeciego roku życia. Odczuwanie ciała może odbywać się poprzez doznania czuciowe, które dokonują się w czasie kontaktu ciała $\mathrm{z}$ elementami otoczenia lub dzięki wewnętrznemu wyczuwaniu centralnej części ciała: brzucha i tułowia. Dzieci z różnego typu zaburzeniami często nie mają tej świadomości lub mają ją ograniczoną lub, tak jak w przypadku dzieci ze spektrum autyzmu, charakteryzują się zaburzonym poczuciem tożsamości (Bogdanowicz i in., 1997). Dzięki Metodzie Ruchu Rozwijającego rozwijana jest świadomość własnego ciała, przestrzeni, usprawnienia ruchowego oraz dzielenia przestrzeni $\mathrm{z}$ innymi osobami i nawiązywania z nimi za pomocą ruchu bliskiego kontaktu (Bogdanowicz, 1992). Poznawanie przestrzeni, w której się znajduje się człowiek sprawia, że czuje się w niej pewniej, przez co staje się aktywny i kreatywny podczas ćwiczeń ruchowych (Bogdanowicz i in., 1997). W MRR ogromny nacisk pada na wyrównanie rozwoju sfery ruchowej, kształtowanie umiejętności nawiązywania pozytywnych relacji z innymi osobami poprzez wspólne wrażenia ruchowe, jak również na budowaniu i wzmacnianiu zaufania do siebie i innych (Bogdanowicz, Kasica, 2016). Jest to szczególnie istotne i pomocne w tera- 
pii osób z ASD, które wykazują szczególne trudności w relacjach i komunikacji międzyludzkiej, wynikające $\mathrm{z}$ całego spektrum zaburzeń w zakresie percepcji i interpretacji bodźców, teorii umysłu i sfery emocjonalnej. Biorąc pod uwagę rokowania osób ze spektrum autyzmu jak i potrzeby wchodzenia w interakcje społeczne należy dodatkowo docenić Metodę Ruchu Rozwijającego jako formę komunikacji poprzez ruch.

\section{Literatura:}

1. American Psychiatric Association (2013). Diagnostic and statistical manual of mental disorders: DSM-5. Washington.

2. Benesch, H. (2002). Atlas psychologii, tom II. Warszawa: Prószyński i S-ka.

3. Bogdanowicz, M., Kasica, A. (2016). Ruch Rozwijający dla wszystkich. Gdańsk: Wydawnictwo Harmonia.

4. Bogdanowicz, M., Kisiel, B., Przasnyska, M. (1997). Metoda Weroniki Sherborne w terapii i wspomaganiu rozwoju dziecka. Warszawa: Wydawnictwa Szkolne i Pedagogiczne.

5. Cotugno, A.J. (2011). Terapia grupowa dla dzieci z zaburzeniami ze spektrum autyzmu. Rozwijanie kompetencji i umiejętności społecznych. Warszawa: Fraszka Edukacyjna Sp. z o.o.

6. Dokowicz, M. (2015). Metoda Ruchu Rozwijajqcego Weroniki Sherborne. Pobrane z: https://pedagogika -specjalna.edu.pl/warsztat-pracy/metoda-ruchu-rozwijajacego-weroniki-sherborne/

7. Grandin, T., Panek, R. (2017). Mózg autystyczny. Podróż w głąb niezwykłych umysłów. Kraków: Copernicus Center Press Sp. z o.o.

8. Hill, C. (2013). Komunikacja poprzez ruch. Ruch Rozwijający Sherborne dążenie do poszerzania perspektyw. Warszawa: Centrum Szkoleniowo-Wydawnicze Arteer Elżbieta Rybicka.

9. Kaczmarek, B., Wojciechowska, A. (red.) (2015). Autyzm i AAC Alternatywne i wspomagające sposoby porozumiewania się w edukacji osób z autyzmem. Kraków: Wydawnictwo Impuls.

10. Kim była Weronika Sherborne (2009). Pobrane z: http://weronikasherborn.blog.onet.pl/2009/05/06/ kim-byla-weronika-sherborne-2/

11. Klinta, C. (1998). Självtillit, kommunikation, rörelseglädje genom Sherborneövningar. Solna: EkelundsFörlag AB.

12. Komender, J., Jagielska, G., Bryńska, A. (2012). Autyzm i Zespół Aspergera. Warszawa: Wydawnictwo Lekarskie PZWL.

13. Okoń, W. (2004). Nowy słownik pedagogiczny. Wydawnictwo Akademickie „Żak” Warszawa: Teresa i Józef Śniecińscy.

14. Pisula, E. (2010). Autyzm przyczyny symptomy terapia. Gdańsk: Wydawnictwo Harmonia.

15. Platt, G. (2015). Pokonać dyspraksję. Prosty program ćwiczeń poprawiających umiejętności ruchowe w domu i w szkole. Gdańsk: Harmonia Uniwersalis.

16. Sherborne, W. (2001). Developmental Movement for Children: Mainstream, special needs and pre-school. London: Worth Publishing.

17. Sherborne, W. (2002). Ruch rozwijajacy dla dzieci. Warszawa: Wydawnictwo Naukowe PWN.

18. Tomczyk, M., Zarych, E. (red.) (2007). Słownik Szkolny Język Polski. Kraków: Wydawnictwo Zielona Sowa.

19. World Health Organization (1992). International classification of diseases: Diagnostic criteria for research (10th edition). Geneva, Switzerland.

20. Zaburzenia ze spektrum autyzmu po zmianach w DSM - V. Pobrane z: https://autyzmwszkole.com/category/zaburzenia-ze-spektrum-autyzmu-po-zmianach-w-dsm-v/ 